\title{
Study on the Driving Factors of Cross-Border Online Consumer Purchase Behaviour
}

\author{
Menghao Zhang ${ }^{1}$, Xuemei Liang ${ }^{2}$, Lihua Zhuo ${ }^{3}$ \\ ${ }^{1}$ Department of ManagementEngineering, Zhengzhou University, Zhengzhou 450001, China \\ ${ }^{2}$ Department of ManagementEngineering, Zhengzhou University, Zhengzhou 450001, China \\ ${ }^{3}$ Department of Information Management, Henan Light Industry Vocational College, Zhengzhou \\ 450001, China \\ \{Menghao Zhang *\}zhangmhyy@163.com
}

Keywords: Cross-border e-commerce; Purchase willingness; Driving factors; Moderation effect; Mediator effect

\begin{abstract}
In recent years, with the rapid development of cross-border e-commerce, increasing number of domestic consumers prefer to purchase overseas products through cross-border online shopping. On the basis of the technology acceptance model and planning action theory, this paper constructs the driving factor model of cross-border online shopping behaviour and makes empirical analysis. The results show that behavioural attitude has a significant positive effect on purchase willingness, and perceived usefulness and perceived ease of use have positive effects on behavioural attitude. Besides, perceived epidemic, perceived value and convenience have moderation effects on behavioural attitude affecting purchase willingness. Based on these results, this paper believes that the key to improve consumers' willingness of cross-border online shopping lies in their behaviour attitude. The positive behaviour attitude can be improved by improving purchase efficiency and expanding product categories. In addition, strategies such as enhancing promotional activities, increasing publicity of positive information on cross-border online shopping and improving relevant technologies of operation systems are proposed to improve cross-border online consumer purchase behaviour.
\end{abstract}

\section{Introduction}

In recent years, with the quick development of e-commerce and the Internet+ model, the scale of China's cross-border e-commerce transactions has witnessed a sustained and rapid growth. Especially, the import retail cross-border e-commerce shows huge potentials with a dramatic increasement. According to the 2017 monitoring report of China's e-commerce market released by China e-commerce research centre, the scale of China's cross-border e-commerce transactions in 2017 was 8.06 trillion yuan, among which the volume of imported cross-border e-commerce transactions was 1.76 trillion yuan, accounting for only 21.8\%. According to Iresearch's study report on China's cross-border online shopping users 2017, cross-border online shopping is now at an early stage of development. The consumption frequency is lower than the overall online shopping evidenced by the fact that about 3/4 users purchase less than once a month. Based on 2016 
China network shopping industry monitoring report, the market penetration rate of cross-border online shopping in China was only 12.6 percent. However, at the same time of low transaction scale and low market penetration rate, the growth rate of China's imported retail cross-border e-commerce is remarkable and has huge potential. The scale of China's cross-border imported retail e-commerce market was about 111.34 billion yuan in 2017, with a growth rate of 49.6 percent, reported by the 2018 research report on the development of China's cross-border imported retail e-commerce industry released by Iresearch. On the basis of the 2016-2017 China cross-border e-commerce market research report, the number of Chinese online shopping users reached 41 million in 2016, with a growth rate of 78.3 percent. From the market compound growth rate of the five years from 2012 to 2016, the annual compound growth rate of imported retail e-commerce was $96.4 \%$ compared with $54.1 \%$ of the cross-border e-commerce and $31.5 \%$ of the entire e-commerce industry.

All the data above indicate that the cross-border e-commerce of import retail has shown vigorous vitality. In this sense, it is significant to make in-depth studies. From the perspective of demand side, cross-border shopping of consumers is significantly different from shopping in China in terms of social demography, shopping category preference, behavioural difference and driving motivation (Lu, lin, Wu, 2015; Dmitrovic and Vida, 2007). In addition, due to the deficiencies in supply chain management such as overseas supplier management and cross-border logistics, the imported retail cross-border e-commerce enterprises have failed to create a nice environment for consumers to adapt to their driving motives, and have brought negative experiences to consumers on credit, security and logistics. Therefore, based on the particularity of the imported retail cross-border shopping and the complexity of its driving factors, in-depth research on the cross-border retail buying behaviour and its driving mechanism is conducive to enriching the theoretical basis for cross-border e-commerce and beneficial to the further development of the imported retail cross-border e-commerce practice. Also, the results of the study can be helpful for the policies making.

\section{Literature Review}

Researches on imported cross-border e-commerce are mainly focused on the driving factors of the consumer behaviour, such as consumers' personal characteristics (e.g., age, occupation, income level, education background, etc.), intrinsic motivation, the product quality, product price, the social paradigm, perceived usefulness, perceived ease of use, perceived risk, imports of cross-border e-commerce policy (Guo and Wang,2009; Zhang, Song and Zhuo, 2017; Wagner et al., 2016; Valarezo et al., 2018). At the same time, some studies have analyzed the incentives of import cross-border policies to consumers' cross-border online shopping behaviour, such as tax policy, customs clearance difficulty, positive list of imports, publicity exposure of bad products(Leal et al., 2010; Martens,2013). However, there is a lack of detailed empirical analysis on the effects of such policies.

\subsection{The relationship between behavioural attitude and purchase willingness}

Many researchers believe that behavioural attitude is an important factor to explain purchase willingness. Yang and Dong (2015) suggested that behavioural attitude is directly related to the emergence of purchase willingness and can be an evaluation of the degree of consumers' liking to perform certain behaviour. Zhang, Bai And Li (2011) believed that consumers' behavioural attitudes can be further subdivided into attitude towards online shopping and attitude towards online information searching. In their study, attitude towards online information searching has a significant impact on online purchase willingness' 


\subsection{The relationship among perceived usefulness, perceived ease of use and behavioural attitude}

Ju, et al. (2017) adopted the mixed selection model to verify the positive influence of perceived usefulness and perceived ease of use on behavioural attitude. Wang (2015) studied the relationship among perceived usefulness and perceived ease of use and behavioural attitude from the perspective of technology acceptance model and task technology matching model integration. This study verified that perceived usefulness and perceived ease of use had positive effects on behavioural attitude. Li and Zhang (2015) used structural equation model to verify that perceived usefulness and perceived ease of use had a significant impact on behavioural attitude. Also, their study showed that the impact of perceived usefulness on behavioural attitude was slightly higher than that of perceived ease of use. Mao, Bian and Li (2016) adopted the improved technology model and used SPSS and VPLS software to test the structural equation model of the questionnaire data. The results showed that both perceived usefulness and perceived ease-of-use have positive effects on behavioural attitudes.

\subsection{The relationship between perceived risk and behavioural attitude}

Bauer (1960) believed that perceived risk included two factors: uncertainty of decision outcome and severity of consequences of wrong decision. Jing and Zhou (2005) divided the perceived risks of consumers into eight aspects, including economic risk, functional risk, physical risk, time risk, privacy risk, service risk, social risk and psychological risk. Also, their study showed that these eight aspects all had negative effects on behavioural attitude. Wu and Tang (2015) argued that online shopping had perceived risks. Based on their study, most consumers would believe that online shopping has certain risks, such as basic information disclosure and after-sale protection unguaranteed. This study also used the method of regression analysis of the questionnaire data to verify that the perceived risk has significant negative influence on consumer behaviour attitude.

\section{Hypothesis and Research Design}

\subsection{Variable definition and research hypothesis}

Based on the literature review and theoretical studies, the definitions for each variable are shown in table 1.

Table 1 Definition of each variable

\begin{tabular}{|c|c|}
\hline $\begin{array}{l}\text { Perceived } \\
\text { usefulness }\end{array}$ & $\begin{array}{l}\text { When purchasing cross-border products online, consumers can effectively improve their } \\
\text { performance in purchasing overseas products }\end{array}$ \\
\hline $\begin{array}{l}\text { Perceived ease } \\
\text { of use }\end{array}$ & How easy it is for consumers to perceive the information of the cross border products \\
\hline Perceived risk & The degree of uncertainty appears during cross-border online shopping behaviros \\
\hline $\begin{array}{l}\text { Behavioral } \\
\text { attitude }\end{array}$ & $\begin{array}{l}\text { Consumers' understanding of cross-border online shopping and subjective judgment of the results, } \\
\text { such as reliable, positive, negative or bad }\end{array}$ \\
\hline $\begin{array}{l}\text { Perceived } \\
\text { epidemic }\end{array}$ & Consumers' subjective evaluation of the popularity of cross-border online shopping at present \\
\hline Perceived value & $\begin{array}{l}\text { The price difference perceived by consumers after comparing the price of cross-border online } \\
\text { shopping with the expected price in their mind }\end{array}$ \\
\hline Convenience & $\begin{array}{l}\text { The sufficient level of the resources required for cross-border online shopping, such as software, } \\
\text { hardware, money and time }\end{array}$ \\
\hline $\begin{array}{l}\text { Purchase } \\
\text { willingness }\end{array}$ & $\begin{array}{l}\text { The possibility or tendency of consumers to purchase overseas goods through cross-border online } \\
\text { shopping }\end{array}$ \\
\hline
\end{tabular}


The hypothesis proposed in this paper is as follows:

H1: In cross-border online shopping, consumer behavioral attitude is positively affected by perceived usefulness.

H2: In cross-border online shopping, consumer behavioral attitude is positively affected by perceived ease of use

H3: In cross-border online shopping, consumer behavioral attitude is negatively affected by perceived risk.

H4: In cross-border online shopping, consumer purchase willingness is positively affected by behavioral attitude.

H5: In cross-border online shopping, environment, perceived epidemic has regulation effect on behavioral attitude and purchase willingness.

H6: In cross-border online shopping, perceived value has regulation effect on behavioral attitude and purchase willingness.

H7: In cross-border online shopping, convenience has regulation effect on behavioral attitude and purchase willingness.

\subsection{Factors selection and measurement}

Based on the literature review and other scholars' researches, this paper measures the variables through the following questions, as shown in table 2.

Table 2 Measurement of variables

\begin{tabular}{|c|c|}
\hline Variables & Measurement of variables \\
\hline $\begin{array}{l}\text { Perceived } \\
\text { usefulness }\end{array}$ & $\begin{array}{l}\text { P1: I think there are more products for me to choose } \\
\text { P2: I think the delivery service is good and the arrival time is fast } \\
\text { P3: I think cross-border products have better quality }\end{array}$ \\
\hline $\begin{array}{l}\text { Perceived } \\
\text { ease of use }\end{array}$ & $\begin{array}{l}\text { P4: I believe the cross-border online shopping process is simple } \\
\text { P5: I believe the cross-border online shopping payment, return and exchange procedures are } \\
\text { simple } \\
\text { P6: I believe cross-border online shopping doesn't need a lot of experience } \\
\text { P7: I believe cross-border online shopping does not have high requirements for foreign languages }\end{array}$ \\
\hline $\begin{array}{l}\text { Perceived } \\
\text { risk }\end{array}$ & $\begin{array}{l}\text { P8: I think paying cross-border products online is risky } \\
\text { P9: I think there are some risks in the transportation of the products } \\
\text { P10: Cross-border online shopping can lead to personal information leaks } \\
\text { P11: I worry that the product buying from cross-border online shopping is different from what I } \\
\text { expect }\end{array}$ \\
\hline $\begin{array}{l}\text { Behavioral } \\
\text { attitude }\end{array}$ & $\begin{array}{l}\text { P12: I believe cross-border online shopping is a good choice } \\
\text { P13:I like to buy overseas products through cross-border online shopping } \\
\text { P14:I believe cross-border online shopping makes me happy }\end{array}$ \\
\hline $\begin{array}{l}\text { Perceived } \\
\text { epidemic }\end{array}$ & $\begin{array}{l}\text { P15: Cross-border online shopping is very popular among people I know } \\
\text { P16: Many of my friends have experienced cross-border online shopping } \\
\text { P17: My friends on average have good comments on cross-border online shopping }\end{array}$ \\
\hline $\begin{array}{l}\text { Perceived } \\
\text { value }\end{array}$ & $\begin{array}{l}\text { P18: I think cross-border online shopping offers more discounts } \\
\text { P19: The product price of cross-border online shopping is lower than I expected } \\
\text { P20: I think it is cheaper to buy overseas products through cross-border online shopping }\end{array}$ \\
\hline Convenience & $\begin{array}{l}\text { P21: I have hardware and software to do cross-border online shopping } \\
\text { P22: I have time for cross-border shopping } \\
\text { P23: I can afford the cost of cross-border online shopping (transportation fee, handling fee, etc.) }\end{array}$ \\
\hline $\begin{array}{l}\text { Purchase } \\
\text { willingness }\end{array}$ & $\begin{array}{l}\text { P24: When buying overseas products in the future, I will chose to use cross-border online shopping } \\
\text { P25: I would like to recommend to my friends to buy overseas brand products through } \\
\text { cross-border online shopping. } \\
\text { P26: I would like to follow information about overseas products online }\end{array}$ \\
\hline
\end{tabular}




\subsection{Questionnaire design and collection}

The questionnaire was made based on the measurement of variables. Also, the questionnaire included statistics of the demographic characteristics and the past cross-border online shopping experience of consumers. Respondents were asked to rate the questions according to the likert scale, which used 1 to 5 to indicate the range of degree of complete disagreement to complete agreement. The questionnaires have been sent and received in four months through both papers and online. A total of 400 samples were sent, and 387 were received. After excluding the questionnaires whose respondents did not have online purchase for cross-border retail products, and those with highly regular answers and short response time, the final valid questionnaires were 188.

\section{Research Design and Data Analysis}

\subsection{Reliability and validity test}

This paper tests the reliability of 8 variables including perceived usefulness, perceived ease of use, perceived risk, behavioural attitude, perceived epidemic, perceived value, convenience and purchase willingness in the survey scale. The test results are shown in table 3. Generally speaking, the higher Cronbach's Alpha is, the higher the reliability of the scale is. According to table 3, the Cronbach's Alpha value of the total table is 0.849, and the Cronbach's Alpha values of all 8 variables are above 0.7 respectively. This indicates that the items in the survey scale in this paper have a good consistency, and the selection of measurement variables is reasonable.

Table 3 Reliability test

\begin{tabular}{lll}
\hline Cronbach's Alpha & & Terms \\
.849 & & 8 \\
\hline measured variable & Cronbach's value & items \\
Perceived usefulness & 0.765 & 3 \\
Perceived ease of use & 0.750 & 4 \\
Perceived risk & 0.781 & 4 \\
behavioral attitude & 0.797 & 3 \\
perceived epidemic & 0.827 & 3 \\
perceived value & 0.827 & 3 \\
convenience & 0.863 & 3 \\
purchase willingness & 0.787 & 3 \\
\hline
\end{tabular}

This paper tests the content validity by using the expert evaluation method to o evaluate the content questionnaire scale. By inviting relevant experts scoring on the correlation degree between specific items and contents of the scale statement, this paper deletes questions with low scores. The results show that the questionnaire has good content validity.

When it comes to structural validity test, the scale in this paper contains 8 aspects, including perceived usefulness, perceived ease of use, perceived risk, behavioural attitude, perceived epidemic, perceived value, convenience and purchase willingness. The eight aspects are divided into three parts to do the structure validity tests. The first part contains the perceived usefulness, perceived ease of use, perceived risk. The results show that KMO coefficient value is 0.747 , which is greater than 0.5 . Also, sig $=0.000$ lower than the significance level of 0.05 . The total variance interpretation rate has a high value of $67.782 \%$. The second part contains behavioural attitude and purchase willingness. The KMO test and Bartlett sphericity test results show that KMO coefficient value is 0.806 , which is greater than 0.5 . Also, sig $=0.000$ lower than the significance level of 0.05 . The total variance interpretation rate has a high value of $71.150 \%$. The third part contains the perceived epidemic, perceived value, convenience. The KMO test and Bartlett sphericity test results 
show that KMO coefficient value is 0.816 , which is greater than 0.5 . Also, sig $=0.000$ lower than the significance level of 0.05 . The total variance interpretation rate has a high value of $76.8 \%$. Hence, based on the analysis above, the factor loading coefficients of corresponding measured item are greater than 0.5 respectively. Also, the factor loading coefficients of non-corresponding measured item are less than 0.5 respectively. The results indicate that the scale of questionnaire has good structure validity.

\subsection{Descriptive statistics}

Table 4 Descriptive statistics of the sample

\begin{tabular}{|c|c|c|c|}
\hline Variables & Variable level & Ratio & Frequency \\
\hline \multirow{2}{*}{ Gender } & Male & $34.5 \%$ & 69 \\
\hline & Female & $65.5 \%$ & 131 \\
\hline \multirow{4}{*}{ Age } & Under 18 & $2 \%$ & 4 \\
\hline & $18-24$ years old & $75.5 \%$ & 151 \\
\hline & 24-30 years old & $17 \%$ & 34 \\
\hline & Above 30 & $5.5 \%$ & 11 \\
\hline \multirow{4}{*}{ Level of education } & High school and below junior & $4 \%$ & 8 \\
\hline & college & $4.5 \%$ & 9 \\
\hline & undergraduate & $55 \%$ & 110 \\
\hline & Master and above & $36.5 \%$ & 73 \\
\hline \multirow{5}{*}{$\begin{array}{l}\text { Monthly consumption } \\
\text { level }\end{array}$} & Under 800 yuan & $10.5 \%$ & 21 \\
\hline & 800-1200 yuan & $36.5 \%$ & 73 \\
\hline & $1200-1600$ yuan & $27 \%$ & 54 \\
\hline & $1600-2000$ yuan & $10.5 \%$ & 21 \\
\hline & 2000 yuan & $15.5 \%$ & 31 \\
\hline
\end{tabular}

Descriptive statistics of the demographic characteristic are shown in table 4. Based on the results of table 4, there are 69 male samples and 131 female samples, respectively accounting for 34.5\% and $65.5 \%$ of the effective samples. From the survey data of this paper, it can be seen that women are the main force in cross-border online shopping, which stems from their role characteristics. Women are born to be shopping crazy, and their desire for shopping is much higher than men. Moreover, women regard cross-border online shopping as an entertainment activity and enjoy it. In this process, women's mood will be relaxed, with a pleasant mood to search and buy products, which is also a female stress reduction method. However, in the eyes of most men, they just buy what they need to buy. Therefore, men usually purchase the required products with a purpose. They buy the products quickly to complete the purchase, and seldom browse online without a purpose. From the point of age structure, about $75.5 \%$ of the respondents are between the ages of 18 to 24 , $17 \%$ of the respondents are between the ages of 20 to 30 years old. In this sense, youth and middle age occupy the main position of cross-border online shopping consumption. This can be explained by the fact that young people like to buy some new products, try new things, and follow the trend of the times due to their passionate, active, imaginative and adventurous characteristics. Also, young people have a relatively stable source of financial and rich experience in purchasing, plus no heavier financial burden of the family. Therefore, they become the main consumers since cross-border online shopping gradually becomes a trend in recent years. By contrast, middle age consumers usually pay more attention to quality and buy products with well-known brand and high quality, such as few household articles for use, digital product. From the level of education, more than 96\% of the respondents received a university or college education. Among them, $4.5 \%$ had college degree and 55\% had bachelor's degree, $36.5 \%$ had master's degree or above. The crowd with high education is good at searching various channels to collect product information and can effectively and smoothly apply now emerge in endlessly emerging technologies and means, such as online 
browsing product details and online community, to have a deeper understanding on the quality of the products and make more informed purchasing decisions. In this sense, it is relatively easy for them to understand and contact cross-border online shopping. Hence, the high educational level in data can be explained. From the perspective of monthly consumption level, 63.5\% of respondents' monthly consumption level is between 800 and 1600 yuan, which is relatively low. This is also one of the factors restricting them from cross-border online shopping. This also indicates great potentials for future cross-border online shopping.

Descriptive statistics of the cross-border online shopping characteristic are shown in table 5. From the results of cross-border shopping frequency over the past year in table 5, it can be seen that the most respondents chose the first and second option, up to 114 people. This number accounts for $57 \%$ of the total sample. In this way, it suggests that cross-border online penetration in the consumer is not high and still has huge development spaces. There are a large number of potential consumers. The data about the ways to purchase overseas commodities (multiple choices), 59\% of respondents like to purchase overseas commodities through the cross-border import e-commerce platform. Normally, there are more types commodities on the platform and more promotion activities. Therefore, the online e-commerce platforms are favoured by the majority of consumers.

$44 \%$ of respondents buy overseas products through online personal agency shopping. This indicates that some consumers do not have high trust in overseas products sold at the e-commerce platform. It may be caused by the fake goods problems of the e-commerce platform from time to time. In this way, finding a reliable personal agent to buy the products instead becomes a good choice for those consumers. $40 \%$ of the respondents purchase overseas products directly from abroad, either themselves or through acquaintances. Nowadays, it is much easier to go abroad and an increasing number of Chinese people travel abroad. As a result, it is convenient and simple to bring home local products for themselves or friends, and the prices are more favorable compared to some channels. Moreover, the quality of the products can be guaranteed. This largely avoids the problems of fake products. Only 23\% of the respondents buy overseas products in the Chinese entity shops. Because of the locations, consumers may need to spend more time and energy to search and buy goods. Also, even with the shopping guide, consumers may feel a better shopping experience but cannot be sure of the authenticity of products. In this sense, it will reduce consumers' trust. In addition, only $20 \%$ of respondents buy overseas products through foreign e-commerce websites. It may be related to the language problems. Also, due to the different habits, consumers may not have a good understanding of the products they are browsing, and the operations may not be very smooth.

Table 5 Descriptive statistics of the cross-border online shopping characteristics

\begin{tabular}{|c|c|c|c|}
\hline $\begin{array}{lllr}\begin{array}{l}\text { Participants' previous online shopping } \\
\text { experience }\end{array} & & \\
\end{array}$ & & frequency & percentage \\
\hline \multirow{4}{*}{$\begin{array}{l}\text { cross-border shopping frequency over the } \\
\text { past year }\end{array}$} & $1 \sim 2$ times & 114 & $57 \%$ \\
\hline & $3 \sim 6$ times & 43 & $21.5 \%$ \\
\hline & 7 11 times & 14 & $7 \%$ \\
\hline & 12 times and above & 29 & $14.5 \%$ \\
\hline \multirow[t]{5}{*}{ Types of overseas purchases } & clothing & 78 & $39 \%$ \\
\hline & food & 71 & $35.5 \%$ \\
\hline & homeware & 13 & $6.5 \%$ \\
\hline & digital & 34 & $17 \%$ \\
\hline & skin care & 130 & $65 \%$ \\
\hline \multirow[t]{5}{*}{ The ways to do overseas purchases } & Chinese entity shops & 46 & $23 \%$ \\
\hline & cross-border import e-commerce platform & 118 & $59 \%$ \\
\hline & foreign e-commerce websites & 40 & $20 \%$ \\
\hline & online personal agency shopping & 88 & $44 \%$ \\
\hline & $\begin{array}{l}\text { directly from abroad, either themselves or through } \\
\text { acquaintances }\end{array}$ & 80 & $40 \%$ \\
\hline
\end{tabular}




\subsection{The moderation effects of perceived epidemic, perceived value and convenience}

The moderation effect of perceived epidemic on behavioural attitude and purchase willingness is verified. The results are shown in table 6 . As a result, in table 6 , the perceived epidemic model 3 has a R2 of 0.425 , and the sig. $=0.000$ meaning the equation is statistically significant. Also, the product term coefficient of perceived epidemic and behavioural attitude is significant with the value of 0.139.In this sense, the perceived epidemic has a moderation effect on the path of behavioural attitude acting on purchase willingness.

Table 6 Test of moderation effect of perceived epidemic

\begin{tabular}{llll}
\hline & Purchase willingness & & \\
Variables & Model1 & Model2 & Model3 \\
\hline $\begin{array}{l}\text { Perceived epidemic } \\
\text { behavioural attitude }\end{array}$ & $0.511^{* * *}$ & $0.335^{* * *}$ & $0.318^{* * *}$ \\
$\begin{array}{l}\text { Perceived epidemic * behavioural attitude } \\
\mathrm{R}^{2}\end{array}$ & & $0.328^{* * *}$ & $0.329^{* * *}$ \\
\hline
\end{tabular}

$* \mathrm{p}<0.05 ; * * \mathrm{p}<0.01 ; * * * \mathrm{p}<0.001$

The moderation effect of perceived value on behavioural attitude and purchase willingness is verified. The results are shown in table 7 . As a result, in table 7, the perceived value model 3 has a R2 of 0.374 and the sig. $=0.000$ meaning the equation is statistically significant. Also, the product term coefficient of perceived value and behavioural attitude is significant with the value of 0.071 . In this sense, the perceived value has a moderation effect on the path of behavioural attitude acting on purchase willingness.

Table 7 Test of moderation effect of perceived value

\begin{tabular}{llll}
\hline & Purchase willingness & & \\
Variables & Model1 & Model2 & Model3 \\
\hline $\begin{array}{l}\text { Perceived value } \\
\text { behavioural attitude }\end{array}$ & $0.415^{* * *}$ & $0.245^{* * *}$ & $0.219^{* * *}$ \\
Perceived value * behavioural attitude & & $0.432^{* * *}$ & $0.442^{* * *}$ \\
$\mathrm{R}^{2}$ & 0.207 & & 0.071 \\
& & 0.368 & 0.374
\end{tabular}

The moderation effect of convenience on behavioural attitude and purchase willingness is verified. The results are shown in table 8 . As a result, in table 8, the convenience model 3 has a R2 of 0.593 and the sig. $=0.000$ meaning the equation is statistically significant. Also, the product term coefficient of convenience and behavioural attitude is significant with the value of 0.135 . In this sense, the convenience has a moderation effect on the path of behavioural attitude acting on purchase willingness.

Table 8 Test of moderation effect of perceived value

\begin{tabular}{llll}
\hline Variables & Purchase willingness & & \\
convenience & Model1 & Model2 & Model3 \\
$\begin{array}{l}\text { behavioural attitude } \\
\text { convenience * behavioural attitude }\end{array}$ & $0.674^{* * *}$ & $0.553^{* * *}$ & $0.511^{* * *}$ \\
R2 & & $0.255^{* * *}$ & $0.256^{* * *}$ \\
\hline
\end{tabular}

Based on the analysis above, the hypothesis 5, 6, 7 are tested to be right. 


\subsection{The mediator effect of behavioural attitude}

This paper uses the steps and judgment conditions proposed by Baron and Kenny (1986) to test the mediator effect of behavioural attitude on the efforts perceived usefulness, perceived ease of use and perceived risk affecting purchase willingness. [15]

The results of Model 1(Independent variable to dependent variable) are shown in table 9. In table 9 , the path coefficient of perceived usefulness on purchase willingness, the one of perceived ease of use on purchase willingness and the one of perceived risk on purchase willingness are all significant.

Table 9 Model 1 (Independent variable to dependent variable)

\begin{tabular}{|c|c|c|c|c|c|c|}
\hline & & & Estimate & S.E. & C.R. & $\mathrm{P}$ \\
\hline $\begin{array}{l}\text { Purchase } \\
\text { willingness }\end{array}$ & $<---$ & $\begin{array}{l}\text { Perceived } \\
\text { usefulness }\end{array}$ & .242 & .082 & 2.955 & .003 \\
\hline $\begin{array}{l}\text { Purchase } \\
\text { willingness }\end{array}$ & $<---$ & $\begin{array}{l}\text { perceived ease of } \\
\text { use }\end{array}$ & .210 & .075 & 2.799 & .005 \\
\hline $\begin{array}{l}\text { Purchase } \\
\text { willingness }\end{array}$ & $<---$ & perceived risk & .203 & .101 & 2.012 & .044 \\
\hline
\end{tabular}

The results of Model 2(Independent variable to intermediate variable) are shown in table 10. It can be seen from table 10 that the path coefficient of perceived usefulness on behavioural attitude and the one of perceived ease of use on behavioural attitude are significant. But, the path coefficient of perceived risk on behavioural attitude is not significant.

Table 10 Model 2(Independent variable to intermediate variable)

\begin{tabular}{|c|c|c|c|c|c|c|}
\hline & & & Estimate & S.E. & C.R. & $\mathrm{P}$ \\
\hline $\begin{array}{l}\text { behavioural } \\
\text { attitude }\end{array}$ & $<---$ & $\begin{array}{l}\text { Perceived } \\
\text { usefulness }\end{array}$ & .259 & .071 & 3.633 & $* * *$ \\
\hline $\begin{array}{l}\text { behavioural } \\
\text { attitude }\end{array}$ & $<---$ & $\begin{array}{l}\text { perceived ease of } \\
\text { use }\end{array}$ & .254 & .065 & 3.904 & $* * *$ \\
\hline $\begin{array}{l}\text { behavioural } \\
\text { attitude }\end{array}$ & $<---$ & perceived risk & .060 & .081 & .746 & .455 \\
\hline
\end{tabular}

The results of Model 3(intermediate variable to dependent variable) are shown in table 11. According to table 11, the path coefficient of behavioural attitude on purchase willingness is significant.

The results of Model4 (Independent variable to both intermediate variable and dependent variable) are shown in table 12 . The fitting index results of the whole model of structural equation are given in table 13. From the comparison of multiple fitting indexes and standard values in the table 13, it can be seen that the fitting index of the model is good. In table 12, the path coefficient of perceived usefulness on behavioural attitude and the one of perceived ease of use on behavioural attitude are significant. While, the path coefficient of perceived usefulness on purchase willingness and the one of perceived ease of use on purchase willingness are not significant. Also, the path coefficient of perceived risk on behavioural attitude and the one of perceived risk on purchase willingness are not significant. Besides, the analysis of the structure equation model is shown in figure 1. 
Table 11 Model 3(intermediate variable to dependent variable)

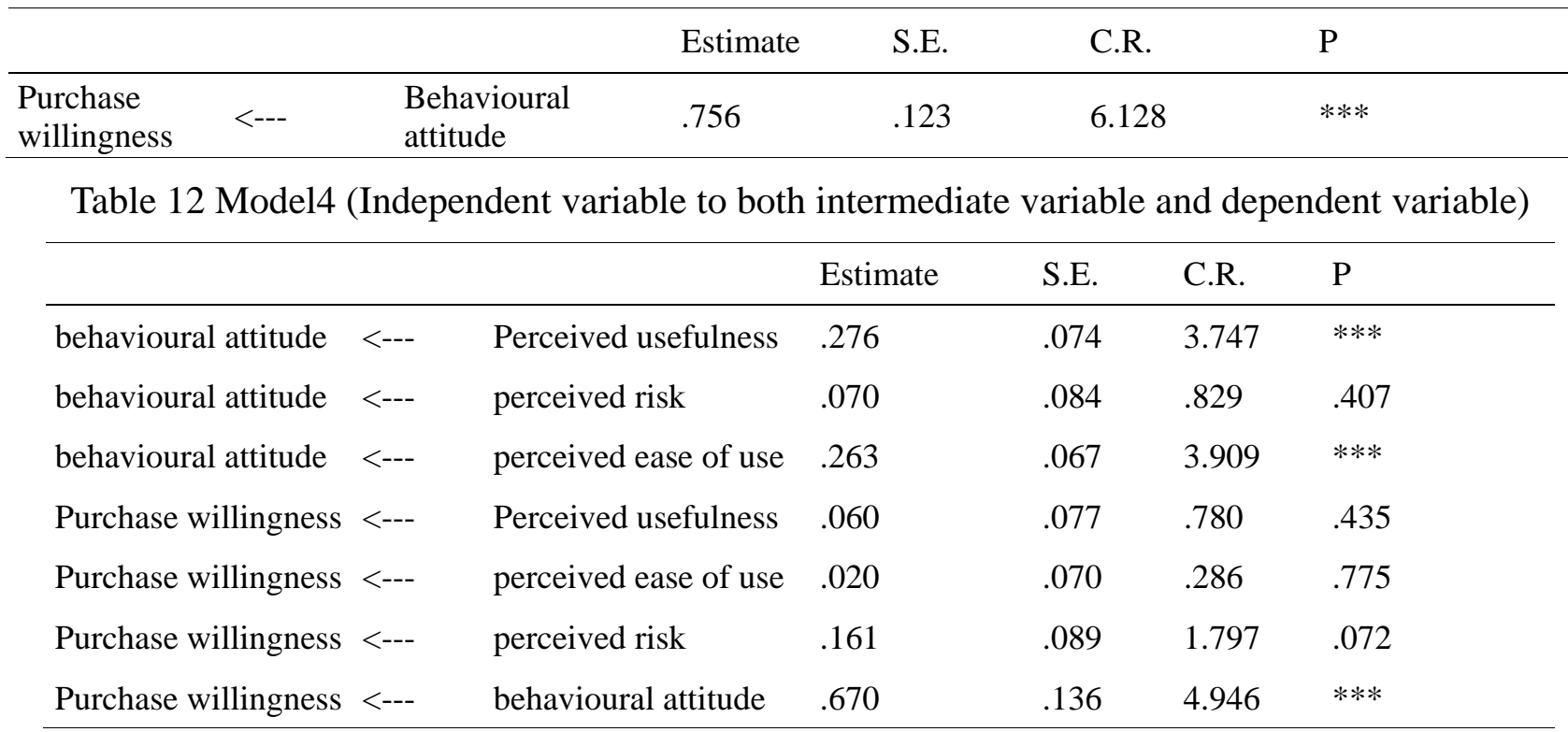

Table 13 The fitting index results

\begin{tabular}{llllll}
\hline & CMIN/DF & AGFI & PGFI & RMSEA & PNFI \\
\hline Index value & 2.481 & 0.798 & 0.624 & 0.089 & 0.646 \\
standard values & $<3$ & $>0.7$ & $>0.5$ & $<0.1$ & $>0.5$ \\
\hline
\end{tabular}

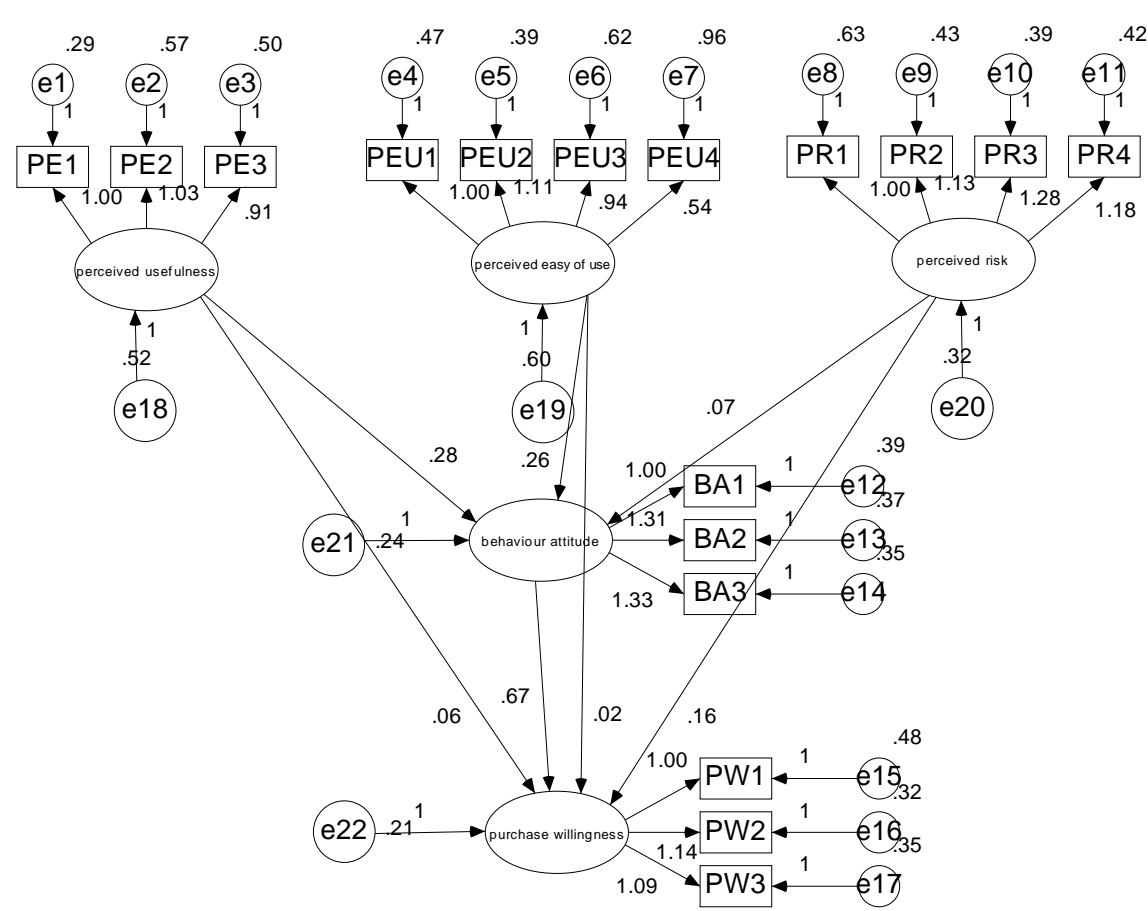

Figure 1 Structure equation model for model 4

Based on the analysis above, according to the test method proposed by Baron and Kenny (1986), behavioural attitude has a complete mediating effect on perceived usefulness affecting purchase willingness and behavioural attitude has a complete mediating effect on perceived ease of use affecting purchase willingness. Also, behavioural attitude has no mediating effect on perceived risk 
affecting purchase willingness. Besides, it can be seen from table 12 that perceived usefulness has a positive effect on behavioural attitude, with a coefficient of $0.276(\mathrm{P}<0.001)$. This is consistent with hypothesis 1 . Perceived ease of use has a positive effect on behaviour attitude, with a coefficient of $0.263(\mathrm{P}<0.001)$. In this way, the hypothesis 2 is tested to be right. The $\mathrm{P}$ value of the coefficient of perceived risk on behavioural attitude is greater than 0.05 . So the hypothesis 3 is not right. Behavioural attitude has a positive effect on purchase willingness with a coefficient of 0.670 $(\mathrm{P}<0.001)$, which is consistent with hypothesis 4 . Accordingly, hypothesis 4 is tested to be right.

\section{Conclusion and Discussion}

By analysis above, the followings conclusions are obtained. (1) Cross-border online purchase willingness is positively influenced by behavioural attitude. When consumers think cross-border online shopping is a good choice and take a positive attitude towards it, they will have the purchase willingness. (2) Behavioural attitude is affected by perceived usefulness, perceived ease of use and perceived risk. Among them, perceived usefulness has the greatest influence on behavioural attitude, followed by perceived ease of use, and perceived risk has the least influence on behavioural attitude. In this sense, when consumers think that cross-border online shopping can improve their shopping experience, they will have a positive attitude towards it. When consumers think that cross-border online shopping can improve their shopping efficiency and make them feel convenient and fast, their attitude towards cross-border online shopping becomes more positive. Meanwhile, when consumers perceive the risk of cross-border online shopping within a certain range, their attitudes towards cross-border online shopping will not fluctuate greatly. (3) Perceived epidemic, perceived value and convenience all have moderating effects on behavioural attitude affecting purchase willingness. The higher the perceived popularity of cross-border online shopping is, the easier it will be for consumers to follow the trend of cross-border online shopping. They will think that cross-border online shopping will help them in their interpersonal communication. Meanwhile, they will reduce their distrust of cross-border online shopping because of the praise from others. When consumers perceive that cross-border online shopping can bring preferential price, they will feel profitable and generate the motivation to adopt cross-border online shopping. When consumers feel that cross-border online shopping is convenient enough and does not require too much time and effort to operate, they will more easily generate cross-border online shopping purchase willingness.

According to the conclusions, suggestions are made as following. (1) It is necessary to expand the categories of overseas products and improve the qualities. With the improvement of people's living conditions, consumers have put forward higher requirements on the categories and qualities of overseas products. In this sense, government departments need to strengthen the quality supervision and avoid the problems of fake goods. It is also essential to punish the merchants selling fake goods strictly. To let consumers perceived more usefulness and less risks make sense. (2) It is also important to improve related technology and simplify operation processes. Consumers like and perceive ease of use with quick shopping. In this way, the platform should continuously improve existing optimization technology, decrease the use difficulty and improve the purchase efficiency. So, it enhances the attraction for consumers, especially first-time cross-border online users.

\section{References}

[1] Baron,R M., Kenny, D A., 1986. The Moderator-Mediator variable distinction in social research: conceptual, strategic and statistical considerations, Journal of Personality and Social Psychology. 51(6), pp. 1173-1182.

[2] Bauer, $R$ A., 1960. Consumer behavior as risk raking, dynamic marketing for a Changing World, Proceedings of the 43rd Conference of the American Marketing Association. pp. 389 - 398. 
[3] Dmitrovic,T., Vida, I., 2007. An examination of cross-border shopping behaviour in South-East Europe, European Journal of Marketing. 41(3/4), pp. 382-395.

[4] Guo, C., Wang, Y J., 2009. A study of cross-border outshopping determinants: mediating effect of out shopping enjoyment, International Journal of Consumer Studies. 33(6), pp. 644-651.

[5] Jing, M., Zhuo, Y., 2005. Research on online purchasing behavior of consumers based on TAM model and perceived risk, Shanghai management science. (05), pp. 5-7.

[6] Ju, P., Zhuo, J., Xu, B., Zhang, J., 2017. Study on car-sharing selection behavior based on hybrid selection model, Transportation system engineering and information. 17(02), pp. 7-13.

[7] Leal, A., Lopez-Laborda, J., Rodrigo, F., 2010. Cross-border shopping: a survey, International Advances in Economic Research. 16(2), pp.135-148.

[8] Li, D H., Zhang, L X., 2015. A study on the influencing factors of tourism App download and use based on TAM, Journal of tourism studies. 30(08), pp. 26-34.

[9] Lu, P., Lin, K., Wu, S L., 2015. Selection of cross-border e-commerce models from consumer experience aspect, Xiamen journal of institute of technology. (4), pp. 39-44.

[10] Mao, P., Bian, Q., Li, L., 2016. Research on user adoption behavior in mobile reading, new century library. (12), pp. 49-53+62.

[11] Martens, B., 2013. What Does Economic Research Tell Us About Cross-Border E-Commerce in the EU Digital Single Market?, Jrc Working Papers on Digital Economy, , Joint Research Centre (Seville site).

[12] Valarezo, U A., Perez A T., Garín, M T., et al.2018. Drivers and Barriers to Cross-Border E-Commerce: Evidence from Spanish Household Behavior, Telecommunications Policy.42 (6), pp. 464-473.

[13] Wagner, G., Schramm-Klein, H., Schu, M., 2016. Determinants and Moderators of Consumers' Cross-Border Online Shopping Intentions, Marketing ZFP. 38(4), pp. 214-227.

[14] Wang, J T., 2015. A study on the factors influencing the adoption of mobile learning behavior by college students -- a case study in a normal university, China remote control. (01), pp. 49-54.

[15] Wu, Z., Tang, M., 2015. Research on consumer channel utilization behavior from the omnichannel perspective, Business research. (02), pp. 152-160.

[16] Yang, Q., Dong, Z R., 2015. Research on the mechanism of early mass buying behavior based on planned behavior theory, Journal of Dalian University of technology (social science edition). 36(01), pp. 70-76.

[17] Zhang, M H., Song, J L., Zhuo, L H., 2017. The study on the purchase willingness of cross-border e-commerce retail products and its influential factors, $3^{\text {rd }}$ International conference on innovation development of e-commerce and logistics. Francis Academic Press. Pp.222-231.

[18] Zhang, H., Bai, C., Li, C., 2011, Consumer network shopping intention analysis--Comparison between rational behavior theory and planned behavior theory, Soft science. 25(09), pp. 130-135. 